\title{
Nematotoxicity of Paeonia spp. Extracts and Camellia oleifera Tea Seed Cake and Extracts to Heterodera glycines and Meloidogyne incognita
}

\author{
Yanhua Wen, ${ }^{1}$ Susan L. F. Meyer, ${ }^{2,}$ Margaret H. MacDonald, ${ }^{2}$ Liuchun Zheng, ${ }^{1}$ Chunyue Jing, ${ }^{1}$ and David J. Chitwood ${ }^{2}$ \\ ${ }^{1}$ Guangdong Province Key Laboratory of Microbial Signals and Disease Control, College of Agriculture, South China Agricul- \\ tural University, Guangzhou 510642, China \\ ${ }^{2}$ United States Department of Agriculture, Agricultural Research Service, Mycology and Nematology Genetic Diversity and \\ Biology Laboratory, Beltsville, MD 20705, U.S.A.
}

\begin{abstract}
Tea-oil camellia (Camellia oleifera) is grown for tea seed oil production, with tea seed cake produced as a byproduct. Rather than disposing of the cake, agricultural uses increase the value of oil production. Constituents of $C$. oleifera are also utilized for traditional Chinese medicine, as are compounds produced by tree peony roots. Consequently, the unused C. oleifera cake, and stems from two tree peony species, Paeonia rockii and Paeonia suffruticosa, were studied for compounds antagonistic to soybean cyst nematode (Heterodera glycines) and root-knot nematode (Meloidogyne incognita). Extracts from $C$. oleifera cake and P. rockii stems suppressed hatch and were nematotoxic to second-stage juveniles (J2) of both nematode species. $P$. rockii extracts were more effective than $P$. suffruticosa extracts for decreasing $M$. incognita hatch and $\mathrm{J} 2$

viability. In greenhouse trials with soybean (Glycine max 'Essex'), powdered $C$. oleifera cake applied as a soil amendment suppressed $H$. glycines cysts/g root by up to $66 \%$ compared with nonamended controls. These results indicate that the extracts and cake contain compounds active against $H$. glycines and $M$. incognita, with activity varying between the two Paeonia species. C. oleifera tea seed cake, and constituents of the cake or of $P$. rockii, are candidates for further studies on management of these nematodes.

Keywords: Camellia, Heterodera, management, Meloidogyne, natural product, nematode, Paeonia, plant extract, root-knot nematode, soil amendment, soybean cyst nematode
\end{abstract}

Deregistration of synthetic nematicides has led to development of novel nematicidal compounds, often with a focus on plant-derived compounds. Plants with traditional uses in herbal medicine have been a rich source of materials for research in this area. Two plants that originated in Asia, Camellia oleifera Abel and Paeonia rockii (S.G. Haw \& Lauener) T. Hong \& J.J. Li, have demonstrated nematicidal activity, and were therefore selected for further studies. In addition, a cultivar of the domesticated Paeonia suffruticosa Andrews was studied for comparison with the naturally occurring $P$. rockii.

C. oleifera is grown for production of tea seed oil, and tea seed cake (also called tea seed meal) is a byproduct of oil production. Approximately 7 tons of this cake are produced when a ton of seed oil is extracted, and in China alone, several million tons of the cake are discarded annually (Gong et al. 2018; Hu et al. 2012; Liu et al. 2016). Utilization of the tea seed cake, rather than disposal, increases the value of tea seed oil production.

${ }^{\dagger}$ Corresponding author: S. L. F. Meyer; Susan.L.Meyer@ars.usda.gov

Funding: This research was partially supported by the United States Department of Agriculture, Agricultural Research Service. Partial support was also provided by the Special Fund for Agro-Scientific Research in the Public Interest (China) Grant Number 201503114 to Y. Wen.

Mention of trade names or commercial products in this publication is solely for the purpose of providing specific information and does not imply recommendation or endorsement by the U.S. Department of Agriculture. USDA is an equal opportunity provider and employer.

The author(s) declare no conflict of interest.

Accepted for publication 25 February 2019.

This article is in the public domain and not copyrightable. It may be freely reprinted with customary crediting of the source. The American Phytopathological Society, 2019.
The cake produces compounds, including saponins, that are active against many organisms. For example, a saponin-rich fraction from C. oleifera cake inhibited growth of the bacteria Bacillus subtilis, Escherichia coli, and Staphylococcus aureus and the fungi Aspergillus oryzae, Mucor racemosus, Penicillium glaucum, Rhizopus stolonifer, and Saccharomyces cerevisiae (Hu et al. 2012). The cake is active against mollusks, and the meal has been applied to fields to control snails (Kijprayoon et al. 2014). Ethanolic and methanolic extracts, volatile compounds, and saponins from $C$. oleifera cake were nematicidal to Meloidogyne javanica second-stage juveniles (J2) and suppressed egg hatch, and cake reduced galling and/or numbers of this root-knot nematode in pot trials with banana, Malabar spinach, and water spinach ( $\mathrm{Li}$ et al. 2013a; Yang et al. 2015). Tea seed cake and/or saponin extracts were also active against Meloidogyne incognita (Kofoid \& White) Chitwood and Bursaphelenchus xylophilus in laboratory assays, suppressed $M$. incognita on tomato in pot studies, and reduced $M$. incognita populations in a field test with Trichosanthes kirilowii (Wang et al. 2013). In greenhouse experiments, tea seed cake application to soil also increased abundance of soil microbes and free-living nematodes, and decreased numbers of Meloidogyne spp. and Helicotylenchus spp. (Yang et al. 2018).

The genus Paeonia has long been cultivated in China for ornamental value and use in traditional Chinese medicine (Bao et al. 2018). Species of peony have not been widely investigated for production of nematicidal constituents, but several studies have indicated that such compounds are present in tree peonies. Paeonia suffruticosa and Paeonia moutan were reported as susceptible hosts for $M$. incognita (Park et al. 2007); however, root bark reduced gall formation by M. incognita on tomato and increased shoot weights and plant heights (Kim et al. 2003). Essential oil from $P$. suffruticosa was also nematicidal to $B$. xylophilus (Choi et al. 2007). Because Paeonia roots are utilized in traditional Chinese herbal medicine, the unused stems were studied as a potential source of beneficial plant compounds (Wen et al. 2001). The authors reported that extracts from stems of $P$. rockii (originally listed in the paper as $P$. suffruticosa), an ancestral species found in the 
mountains of northwestern China (Bao et al. 2018), were active against B. xylophilus, Hirschmanniella oryzae, and Meloidogyne arenaria. These results warrant further investigations of Paeonia spp. stem extracts for activity against other nematodes.

The current study was conducted to investigate activity of extracts from $C$. oleifera cakes and $P$. rockii stems against Maryland isolates of M. incognita and Heterodera glycines Ichinohe. To our knowledge, extracts from these plant sources have not been tested against $H$. glycines. Additionally, stem extracts from two tree peony sources, $P$. suffruticosa and $P$. rockii, were compared for nematotoxicity to $M$. incognita. Because $C$. oleifera cake is used as a soil amendment, it was also applied in the greenhouse to determine effects on H. glycines on soybean (Glycine max (L.) Merr.).

\section{Materials and Methods}

Nematode cultures. Meloidogyne incognita (root-knot nematode) race 1 was obtained as previously described (Meyer et al. 2016). Roots were harvested from 2- to 3-month old, greenhousegrown, susceptible pepper (Capsicum annuum) cv. PA-136 plants that had been inoculated with $M$. incognita (originally isolated in Maryland), and egg masses were picked from roots. The plants were maintained in a greenhouse at 24 to $29^{\circ} \mathrm{C}$, with natural and supplemental lighting combined for a 16-h day length. The same greenhouse was used for all nematode cultures and greenhouse plants described in this paper.

Heterodera glycines (soybean cyst nematode) race 3, originally isolated in Maryland, was maintained on greenhouse-grown soybean (Glycine max cv. Essex). Mature females and cysts were dislodged by gently rubbing roots in water. Egg suspensions were poured through nested sieves (\#20/\#60; pore sizes 850/250 $\mu \mathrm{m}$ diameter), collected in a 1-liter graduated cylinder, mixed with $454 \mathrm{~g} /$ liter sucrose solution, and females and cysts that floated to the top after 15 min were collected and washed to remove the sucrose. A rubber stopper was used to crush females and cysts on a sieve (\#60; 250$\mu \mathrm{m}$-diameter pore size) that was partially submerged in a small tray of distilled water, egg suspensions from the tray were washed through nested sieves (\#230/\#500; pore sizes 63/25 $\mu \mathrm{m}$ diameter), and eggs were collected in distilled water.

For bioassays with nematodes, $H$. glycines eggs or $M$. incognita egg masses were placed in $0.6 \%$ sodium hypochlorite for 5-6 min and rinsed with sterile distilled water (SDW). To obtain J2, eggs were placed in a sterile hatching chamber for 3 days.

Preparation of tree peony (P. suffruticosa cv. Shimanishiki) extracts in the United States. Plants were obtained from Sun Nursery (Woodbine, MD), and were maintained in the greenhouse for 7 months. Stems and petioles from 20 plants were cut into $5-\mathrm{cm}-$ long pieces, freeze dried, coarsely ground (Thomas-Wiley, Laboratory Mill Model 4, Swedesboro, NJ), and then finely ground in a Cyclone Sample Mill (UDY Corporation, Fort Collins, CO) equipped with a 1-mm-diameter pore sieve. To prepare extract, $40 \mathrm{~g}$ powdered material was placed into $320 \mathrm{ml}$ of $95 \%$ ethanol $(12.5 \% \mathrm{wt} / \mathrm{vol})$ and maintained at room temperature for 7 days. The extract was filtered through Whatman No. 1 filter paper (Whatman, Clifton, NJ), collected, and the residue was re-extracted in $160 \mathrm{ml}$ of $95 \%$ ethanol for 7 days with gentle stirring on a stir plate. The second extract was also filtered through Whatman No. 1 filter paper, combined with the first extract, and then dried in a rotary evaporator (Heidolph 2 Rotavac, Schwabach, Germany) to nearly dry. The remaining ethanol was removed with a CentriVap Benchtop Concentrator (Labconco, Kansas City, $\mathrm{MO})$. The weight of the dried ethanolic extract was $6.57 \mathrm{~g}$.

Preparation of tree peony $(P$. rockii) extracts in China. Stems of naturally growing tree peony plants were collected from mountains in Hubei Province, China, air-dried, and ground in an electric mill (Xulang model WN-200, Guangzhou, China) to a powder fine enough to pass through a \#10-mesh sieve (2-mm-diameter pore size). To prepare extracts, $1,100 \mathrm{~g}$ of powder was soaked in 8.8 liters of $95 \%$ ethanol $(12.5 \% \mathrm{wt} / \mathrm{vol})$ for 7 days at room temperature, and the ethanol extract was then filtered through Whatman filter paper (Whatman International Ltd., Hangzhou, China). The residue in the flask was re-extracted with 4.4 liters of $95 \%$ ethanol for 5 days. This second extract was then filtered as described above and combined with the first extract. The pooled extracts were concentrated in a

Table 1. Heterodera glycines second-stage juvenile (J2) activity and viability in extracts from camellia (Camellia oleifera) tea seed cake and tree peony (Paeonia rockii) stems. Previously hatched J2 were immersed in the extracts.

\begin{tabular}{|c|c|c|c|c|c|c|c|c|}
\hline \multirow[b]{2}{*}{$\begin{array}{l}\text { Treatment } \\
\mathbf{m g} / \mathbf{m l}^{\mathrm{x}}\end{array}$} & \multicolumn{4}{|c|}{ Camellia oleifera } & \multicolumn{4}{|c|}{ Paeonia rockii } \\
\hline & Day $1^{y}, \%$ active & Day $2, \%$ active & Day $3, \%$ active & $\begin{array}{c}\text { Days 4-6 rinsed } \\
\% \text { viable }\end{array}$ & Day $1, \%$ active & Day $2, \%$ active & Day 3, \% active & $\begin{array}{c}\text { Days 4-6 rinsed } \\
\% \text { viable }\end{array}$ \\
\hline Water & $80.1 \mathrm{a}$ & $76.6 \mathrm{a}$ & $73.2 \mathrm{a}$ & $71.4 \mathrm{a}$ & $80.1 \mathrm{a}$ & $76.6 \mathrm{a}$ & $73.2 \mathrm{a}$ & $71.4 \mathrm{a}$ \\
\hline 1.0 & $77.7 \mathrm{a}(97.0 \%)^{\mathrm{Z}}$ & $61.3 b^{* *}(80.0 \%)$ & $61.9 \mathrm{~b} * * *(84.6 \%)$ & $52.0 \mathrm{~b}^{* * *}(72.8 \%)$ & 79.9 a $(99.8 \%)$ & $62.2 \mathrm{~b}^{* * *}(81.2 \%)$ & $48.4 \mathrm{~b}^{* * *}(66.1 \%)$ & $55.7 \mathrm{~b} * *(78.0 \%)$ \\
\hline 2.5 & $20.0 \mathrm{~b}^{* * * *}(25.0 \%)$ & $12.1 \mathrm{c}^{* * *}(15.8 \%)$ & $13.7 \mathrm{c}^{* * *}(18.7 \%)$ & $39.4 \mathrm{c}^{* * * *}(55.2 \%)$ & $19.0 \mathrm{~b} * * * *(23.7 \%)$ & $17.9 \mathrm{c}^{* * *}(23.4 \%)$ & $2.7 \mathrm{c}^{* * *}(3.7 \%)$ & $24.3 \mathrm{c} * * * *(34.0 \%)$ \\
\hline 5.0 & $0.8 \mathrm{c} * * * *(1.0 \%)$ & $0.0 \mathrm{~d}^{* * * *}(0 \%)$ & $0.0 \mathrm{~d} * * * *(0 \%)$ & $0.5 \mathrm{~d} * * * *(0.7 \%)$ & $0.0 \mathrm{c} * * * *(0 \%)$ & $0.0 \mathrm{~d} * * * *(0 \%)$ & $0.0 \mathrm{~d}^{* * * *}(0 \%)$ & $0.2 \mathrm{~d} * * * *(0.3 \%)$ \\
\hline
\end{tabular}

${ }^{\mathrm{x}}$ Weight extract per volume water.

y For Day 1 and Days 4-6 rinsed, means within a column followed by the same letter are not significantly different according to Tukey's adjustment for multiple comparisons $(P \leq 0.05)$. For Day 2 and Day 3, means within a column followed by the same letter are not significantly different according to a Kruskal-Wallis test with Wilcoxon each pair nonparametric multiple comparisons $(P \leq 0.05)$. Significance levels of treatment means versus control means are indicated by $*$, $* *$, ***, and $* * * *$ (denoting $P \leq 0.05,0.005,0.001$, and 0.0001 , respectively). Values are means of five replicate wells in each of two trials, for a total of $\mathrm{N}=10$. Nematodes were considered viable if they were active following the water rinse, and nonviable if they were not active.

${ }^{\mathrm{z}}$ Numbers in parentheses are percentages of the corresponding water control.

Table 2. Heterodera glycines egg hatch and second-stage juvenile activity in extracts from camellia (Camellia oleifera) tea seed cake and tree peony (Paeonia rockii) stems. Eggs were immersed in the extracts.

\begin{tabular}{|c|c|c|c|c|c|c|}
\hline \multirow{2}{*}{$\begin{array}{l}\text { Treatment } \\
\mathrm{mg} / \mathrm{ml}^{\mathrm{x}}\end{array}$} & \multicolumn{6}{|c|}{ Camellia oleifera } \\
\hline & Day $3^{y}$ Hatch & Day $3, \%$ active & Day 5 Hatch & Day $5, \%$ active & Day 7 Hatch & Day $7, \%$ active \\
\hline Water & $31.2 \mathrm{a}$ & $87.3 \mathrm{a}$ & $34.3 \mathrm{a}$ & $70.3 \mathrm{a}$ & $36.4 \mathrm{a}$ & $62.9 \mathrm{a}$ \\
\hline 1.0 & $24.3 \mathrm{ab}(77.9 \%)^{\mathrm{z}}$ & $51.2 \mathrm{~b}^{* * * *}(58.6 \%)$ & $25.7 \mathrm{ab}(74.9 \%)$ & $43.1 \mathrm{~b}^{* * * *}(61.3 \%)$ & 35.9 a $(98.6 \%)$ & $45.7 \mathrm{~b}^{*}(72.7 \%)$ \\
\hline 2.5 & $19.5 \mathrm{ab}(62.5 \%)$ & $51.9 \mathrm{~b} * * * *(59.5 \%)$ & $20.7 b^{*}(60.3 \%)$ & $28.6 \mathrm{c}^{* * * *}(40.7 \%)$ & 27.8 a $(76.4 \%)$ & $29.4 \mathrm{c} * * * *(46.7 \%)$ \\
\hline 5.0 & $14.7 b^{* *}(47.1 \%)$ & $42.1 \mathrm{~b}^{* * * * *}(48.2 \%)$ & $16.6 b^{* *}(48.4 \%)$ & $19.2 \mathrm{c} * * * *(27.3 \%)$ & $17.2 \mathrm{~b}^{* * * *}(47.3 \%)$ & $6.5 \mathrm{~d} * * * *(10.3 \%)$ \\
\hline
\end{tabular}

\footnotetext{
${ }^{\mathrm{x}}$ Weight extract per volume water.

y For all days, means within a column followed by the same letter are not significantly different according to Tukey's adjustment for multiple comparisons $(P \leq 0.05)$. Significance levels of treatment means versus control means are indicated by * **, ***, and **** (denoting $P \leq 0.05,0.005,0.001$, and 0.0001 , respectively). Values are means of five replicate wells in each of two trials, for a total of $\mathrm{N}=10$.

${ }^{\mathrm{z}}$ Numbers in parentheses are percentages of the corresponding water control.
} 
rotary evaporator (EYELA N-1100 Rotary Evaporator, Japan). The weight of the dried ethanolic extract was $63.14 \mathrm{~g}$.

Preparation of $\boldsymbol{C}$. oleifera tea cake extracts in China. The tea cakes were purchased from Guangdong Baohua Biotechnology Co. Ltd. (Guangdong Province, China), air-dried, ground in an electric mill, and prepared as described for tree peony in China. A total of $1,000 \mathrm{~g}$ powder was used to make extracts; weight of the dried ethanolic extract was $63.09 \mathrm{~g}$.

Laboratory bioassays. Extracts for assays were dissolved in $40^{\circ} \mathrm{C}$ $\mathrm{SDW}$ at $0.02 \mathrm{wt} / \mathrm{vol}$ (e.g., $0.15 \mathrm{~g}$ extract in $7.5 \mathrm{ml}$ water). Extracts were then filtered through 1.0, 0.45 , and $0.2 \mu \mathrm{m}$ filter syringes (Nalgene, Rochester, NY) as needed, depending on the extract density at the time of preparation, and diluted in SDW to prepare treatment concentrations.

Laboratory assays with previously hatched $\mathrm{J} 2$ were conducted in 48-well or 96-well polystyrene plates, modified from procedures in Meyer et al. (2006). Wells each received an equal amount of extract and $\mathrm{J} 2$ suspension in SDW ( $250 \mu \mathrm{l}$ of each in 48-well plates, $100 \mu \mathrm{l}$ of each in 96-well plates), resulting in ca. $0.2 \mathrm{~J} 2$ per $\mu 1$ in each well. $\mathrm{J} 2$ activity was counted in extracts for at least 2 days, wells were rinsed with SDW on Day 2 or Day 3, and J2 activity counted again after 1 to 3 days of incubation in SDW to determine whether treatments were nematotoxic or nematostatic. J2 were counted as active if they showed any movement within $5 \mathrm{~s}$, and inactive if there was no movement during that time. $\mathrm{J} 2$ that were inactive after the water rinse were considered dead.

For laboratory assays with immersed $M$. incognita eggs, aqueous suspensions of eggs at various developmental stages were adjusted to include 50 eggs that each contained either a first-stage juvenile (J1) or $\mathrm{J} 2$ per $100 \mu \mathrm{l}$. Each well of a 96-well polystyrene plate received $100 \mu \mathrm{l}$ of egg suspension and $100 \mu \mathrm{l}$ of extracts. Assays with immersed $H$. glycines eggs were similar, except that each well contained ca. 100 total eggs. The total hatched $\mathrm{J} 2$, and numbers of inactive/active $\mathbf{J} 2$ that had hatched, were counted at Day 2 or Day 3, Day 5, and Day 7.

Treatments were $1.0,2.5$, and $5.0 \mathrm{mg}$ extract $/ \mathrm{ml}$ for $M$. incognita and $H$. glycines $\mathrm{J} 2$ assays with camellia cake and $P$. rockii extracts, and $0.25,0.5,1.0$, and $5.0 \mathrm{mg} / \mathrm{ml}$ for assays comparing $P$. rockii and $P$. suffruticosa extracts. All assays included a SDW control. Water $+50 \mu \mathrm{g} / \mathrm{ml}$ kanamycin monosulfate (Phytotechnology Laboratories, Shawnee Mission, KS) was also added as a control to assays with immersed M. incognita eggs, due to bacterial contamination in initial assays. For all assays, each treatment was replicated in 5 wells in each of two trials, for a total of $n=10$ per treatment. The microwell plates were covered by plastic adhesive sealing film (Excel Scientific, Inc., Victorville, CA) and the lids sealed with Parafilm (Bemis, Neenah, WI). The plates were incubated at $27^{\circ} \mathrm{C}$.

Greenhouse trials with camellia tea cake soil amendment, H. glycines, and soybean. Camellia cake powder, ground as described for extract preparations, was mixed with steamed and airdried loamy sand enriched soil (16 parts sand:9 parts compost, $\mathrm{vol} / \mathrm{vol} ; 85.1 \%$ sand, $7.2 \%$ silt, $7.6 \%$ clay, $\mathrm{pH} 6.9 ; 0.6 \%$ organic matter). Three soil amendment rates were hand-mixed into the soil: 1.5 $\mathrm{g} / 300 \mathrm{ml}$ soil $(0.5 \% \mathrm{wt} / \mathrm{vol}), 2.25 \mathrm{~g} / 300 \mathrm{ml}$ soil $(0.75 \% \mathrm{wt} / \mathrm{vol})$ and $3.0 \mathrm{~g} / 300 \mathrm{ml}$ soil $(1.0 \% \mathrm{wt} / \mathrm{vol})$, placed into 10 -cm-diameter pots, and the soil was watered. Soybean (cv. Essex) seedlings
(9-11 days old) were then removed from Promix PGX (Premier Tech Horticulture, Quakertown, PA), the roots were dipped in water to remove the potting mix, and one seedling was transplanted into each pot. Each $H$. glycines-inoculated plant received 2,000 total $H$. glycines eggs in $2 \mathrm{ml}$ water (pipetted into 3 holes around the base of each plant). The treatments were: 1$) 1.5 \mathrm{~g}$ camellia powder $+H$. glycines eggs; 2) 2.25 g powder + eggs; 3) 3.0 g powder + eggs; 4) Water + eggs; and 5) Water, No H. glycines. Pots were arranged in a randomized complete block design. Plants were harvested 33 days after transplant. Shoot fresh weights were recorded, and shoots were then placed in a $60^{\circ} \mathrm{C}$ oven for 7 days and shoot dry weights recorded. Cysts were collected from root balls as described above for $\mathrm{H}$. glycines inoculum, except that the cysts were not crushed. Instead, the cyst suspension was poured onto on a 90-mm-diameter ruled filter paper in a Buchner funnel under a vacuum. The filter paper was then placed in the lid of a 100-mm-diameter petri dish and cysts were counted under a dissecting microscope. Roots were damp-dried with paper towels and weighed. Two trials were conducted, with 10 pots per treatment in each trial, for a total $n=20$ per treatment.

Statistical analyses. Data were analyzed with the statistical package JMP 11.2.0 (sAs Institute, Cary, NC). Differences among treatments were determined by ANOVA, and means were compared using Tukey Kramer's adjustment for multiple comparisons $(P \leq$ 0.05). For nonparametric data, a Kruskal-Wallis test with Wilcoxon each pair nonparametric multiple comparisons was used to determine differences $(P \leq 0.05)$ among means. The analysis used for each treatment is indicated in the footnote of each table.

\section{Results}

Activity of camellia tea seed cake extract and $P$. rockii stem extract against $\boldsymbol{H}$. glycines in vitro. Both types of extracts were nematotoxic to previously hatched $H$. glycines J2 (Table 1 ). By Day 1 , the two highest concentrations of camellia extract, $2.5 \mathrm{mg} / \mathrm{ml}$ and $5.0 \mathrm{mg} / \mathrm{ml}$, reduced $\mathrm{J} 2$ activity by 75 and $99 \%$, respectively. By Day 2, all three tested concentrations suppressed $\mathbf{J} 2$ activity. The $5.0 \mathrm{mg} / \mathrm{ml}$ was the most effective, resulting in $100 \%$ loss of $\mathrm{H}$. glycines $\mathrm{J} 2$ activity. Camellia extract at $5.0 \mathrm{mg} / \mathrm{ml}$ was the most nematotoxic, resulting in $99 \%$ reduction in $\mathrm{J} 2$ viability compared with the water control after a SDW rinse.

The $P$. rockii extracts were the most effective at the 2.5 and $5.0 \mathrm{mg} / \mathrm{ml}$ concentrations, with $0 \% \mathrm{~J} 2$ active on Days $1-3$ in $5.0 \mathrm{mg} / \mathrm{ml}$, and a $99.7 \%$ reduction in viable $\mathrm{J} 2$ after the water rinse (Table 1). Immersion of $\mathrm{J} 2$ in $2.5 \mathrm{mg} / \mathrm{ml} P$. rockii extract resulted in up to a $96.3 \%$ loss of $\mathrm{J} 2$ activity by Day 3 , but the reduction in $\mathrm{J} 2$ viability after the water rinse was $66 \%$.

Extracts from both plants also inhibited $H$. glycines hatch and viability of $\mathrm{J} 2$ that hatched from immersed eggs (Table 2). In camellia extracts, hatch was decreased by the highest concentration $(5.0 \mathrm{mg} / \mathrm{ml})$ by Day 3 , and was suppressed by $53 \%$ by Day 7 . The lowest concentration did not inhibit hatch, while the $2.5 \mathrm{mg} / \mathrm{ml}$ showed a significant suppression on Day 5. However, all three concentrations inhibited $\mathbf{J} 2$ activity on all days (Table 2). The two highest concentrations were the most effective, with the $5.0 \mathrm{mg} / \mathrm{ml}$ suppressing activity by $90 \%$ on Day 7 . Although effects on previously hatched J2 versus immersed $\mathbf{J} 2$ were not tested in the same assays, the results

Table 2. (Continued from previous page)

\begin{tabular}{|c|c|c|c|c|c|}
\hline \multicolumn{6}{|c|}{ Paeonia rockii } \\
\hline Day 3 Hatch & Day 3, \% active & Day 5 Hatch & Day $5, \%$ active & Day 7 Hatch & Day $7, \%$ active \\
\hline $31.2 \mathrm{a}$ & $87.3 \mathrm{a}$ & $34.3 \mathrm{a}$ & $70.3 \mathrm{a}$ & $36.4 \mathrm{ab}$ & $62.9 \mathrm{a}$ \\
\hline 27.7 a $(88.8 \%)$ & 85.6 a $(98.1 \%)$ & 35.8 a $(104.4 \%)$ & $60.6 \mathrm{ab}(86.2 \%)$ & 39.5 a $(108.5 \%)$ & $48.2 b^{*}(76.6 \%)$ \\
\hline $25.8 \mathrm{a}(82.7 \%)$ & 79.5 a $(91.1 \%)$ & 28.0 a $(81.6 \%)$ & $51.4 \mathrm{bc}^{*}(73.1 \%)$ & $29.3 \mathrm{~b}(80.5 \%)$ & $40.8 \mathrm{~b} * * * *(64.9 \%)$ \\
\hline $15.0 \mathrm{~b}^{* *}(48.1 \%)$ & $67.7 \mathrm{~b} * * * *(77.5 \%)$ & $15.9 \mathrm{~b}^{* * *}(46.4 \%)$ & $39.1 \mathrm{c}^{* * * *}(55.6 \%)$ & $16.1 \mathrm{c} * * * *(44.2 \%)$ & $26.5 \mathrm{c} * * * *(42.1 \%)$ \\
\hline
\end{tabular}


suggested that the camellia extracts were more effective against previously hatched $\mathrm{J} 2$ that were directly immersed in the treatments (Tables 1 and 2).

With $P$. rockii, the $5.0 \mathrm{mg} / \mathrm{ml}$ extract was the most effective against H. glycines in immersed egg assays (Table 2). This concentration inhibited hatch by $52 \%$ (Day 3) to 56\% (Day 7). The lower concentrations were not effective in decreasing hatch. By Day 3, activity of hatched $\mathrm{J} 2$ was decreased by $23 \%$ in the highest concentration of $P$. rockii extract. By Day 7, all three concentrations inhibited $\mathrm{J} 2$ activity, with $5.0 \mathrm{mg} / \mathrm{ml}$ resulting in the least $\mathrm{J} 2$ activity (58\% decrease compared with the water control). As with the camellia extract, the results suggested that the $P$. rockii extract decreased viability of previously hatched $\mathrm{H}$. glycines $\mathrm{J} 2$ more than viability of $\mathrm{J} 2$ that hatched from immersed eggs (Tables 1 and 2).

Activity of camellia tea seed cake extract and $P$. rockii stem extract against $M$. incognita in vitro. Extracts from $C$. oleifera cake and $P$. rockii stems were nematotoxic to previously hatched $\mathrm{J} 2 \mathrm{im}-$ mersed directly into the treatments (Table 3). On Day 1, all concentrations of camellia extracts resulted in small but significant decreases in $\mathbf{J} 2$ activity. By Day 2, $\mathbf{J} 2$ activity in camellia extracts was less than half that in the water control. The $2.5 \mathrm{mg} / \mathrm{ml}$ treatment resulted in the fewest active $\mathbf{J} 2$ on Day 3 . All three camellia extract treatments resulted in high mortality (Day 6 after rinse), with the two highest rates resulting in 94 to $96 \%$ greater $\mathrm{J} 2$ mortality than in the water control.

$P$. rockii extracts also reduced activity of immersed $\mathrm{J} 2$ by Day 1 (Table 3). The highest rate $(5.0 \mathrm{mg} / \mathrm{ml})$ was the most effective in inhibiting $\mathrm{J} 2$ activity on Days 1, 2, and 3, resulting in 62 to $70 \%$ decreases compared with the water control (Table 3 ). All three rates of tree peony extract resulted in similar numbers of nonviable $\mathrm{J} 2$, decreasing viability by 57 to $69 \%$.

Camellia cake and $P$. rockii extracts also inhibited $M$. incognita hatch and activity of $\mathrm{J} 2$ that hatched from immersed eggs (Table 4). Because the antibiotic kanamycin monosulfate was used in all extract treatments to stop growth of bacteria, effects on hatch and $\mathrm{J} 2$ activity were compared with the kanamycin control. By Day 5, the two highest concentrations of camellia extract inhibited hatch. All three concentrations were effective by Day 7, with hatch inhibited by 41 to $69 \%$ in the extract treatments. Activity of $\mathrm{J} 2$ that hatched from the eggs was decreased by all camellia extract treatments on all days, with $5.0 \mathrm{mg} / \mathrm{ml}$ resulting in no active $\mathrm{J} 2$ on Days 5 and 7 , and $2.5 \mathrm{mg} / \mathrm{ml}$ extract causing a $99 \%$ reduction in $\mathrm{J} 2$ activity by Day 7 .

With $P$. rockii extracts, the highest concentration had the greatest effect, with little or no effect at the lower concentrations (Table 4). On Day 3, $5.0 \mathrm{mg} / \mathrm{ml}$ suppressed hatch and $\mathrm{J} 2$ activity by 87 and $92 \%$, respectively. By Day 7, hatch in the $5.0 \mathrm{mg} / \mathrm{ml}$ extract was decreased by $94 \%$, and $\mathrm{J} 2$ activity by $80 \%$.

Assays comparing activity of stem extracts from two tree peony sources against $M$. incognita in vitro. Extracts from two tree peony taxa were compared for activity against previously hatched $M$. incognita $\mathrm{J} 2$ (Table 5). As with the $P$. rockii extract assays tested at the same time as camellia (Table 3), the P. suffruticosa and $P$. rockii extracts were consistently effective on all days for reducing

Table 3. Meloidogyne incognita second-stage juvenile (J2) activity and viability in extracts from camellia (Camellia oleifera) tea seed cake and tree peony (Paeonia rockii) stems. Previously hatched J2 were immersed in the extracts.

\begin{tabular}{|c|c|c|c|c|c|c|c|c|}
\hline \multirow[b]{2}{*}{$\begin{array}{l}\text { Treatment } \\
\text { mg/ml }\end{array}$} & \multicolumn{4}{|c|}{ Camellia oleifera } & \multicolumn{4}{|c|}{ Paeonia rockii } \\
\hline & $\begin{array}{c}\text { Day 1y } \\
\% \text { active }\end{array}$ & $\begin{array}{c}\text { Day } 2 \\
\% \text { active }\end{array}$ & $\begin{array}{c}\text { Day } 3 \\
\% \text { active }\end{array}$ & $\begin{array}{c}\text { Day } 6 \text { rinsed } \\
\% \text { viable }\end{array}$ & $\begin{array}{c}\text { Day } 1 \\
\% \text { active }\end{array}$ & $\begin{array}{c}\text { Day } 2 \\
\% \text { active }\end{array}$ & $\begin{array}{l}\text { Day } 3^{y} \\
\% \text { active }\end{array}$ & $\begin{array}{c}\text { Day } 6 \text { rinsed } \\
\% \text { viable }\end{array}$ \\
\hline Water & $89.4 \mathrm{a}$ & $86.6 \mathrm{a}$ & $86.8 \mathrm{a}$ & $71.7 \mathrm{a}$ & $89.4 \mathrm{a}$ & $86.6 \mathrm{a}$ & $86.8 \mathrm{a}$ & $71.7 \mathrm{a}$ \\
\hline 1.0 & $\begin{array}{l}75.8 \mathrm{~b}^{* *} \\
(84.8 \%)^{\mathrm{z}}\end{array}$ & $\begin{array}{l}37.6 \mathrm{~b}^{* * * * *} \\
(43.4 \%)\end{array}$ & $\begin{array}{l}46.1 \mathrm{bc} * * * * \\
(53.1 \%)\end{array}$ & $\begin{array}{l}11.3 \mathrm{~b}^{* * * * *} \\
(15.8 \%)\end{array}$ & $\begin{array}{l}60.4 \mathrm{~b} * * * * \\
(67.6 \%)\end{array}$ & $\begin{array}{l}58.2 \mathrm{~b}^{* * * * *} \\
(67.2 \%)\end{array}$ & $\begin{array}{l}47.2 \mathrm{~b}^{* * * *} \\
(54.4 \%)\end{array}$ & $\begin{array}{l}30.6 b^{* * * * *} \\
(42.7 \%)\end{array}$ \\
\hline 2.5 & $\begin{array}{c}76.5 \mathrm{~b}^{*} \\
(85.6 \%)\end{array}$ & $\begin{array}{l}42.4 \mathrm{~b}^{* * * * *} \\
(49.0 \%)\end{array}$ & $\begin{array}{l}28.2 \mathrm{c}^{* * * * *} \\
(32.5 \%)\end{array}$ & $\begin{array}{l}4.2 \mathrm{c}^{* * * * *} \\
(5.9 \%)\end{array}$ & $\begin{array}{l}50.0 \mathrm{~b}^{* * * * *} \\
(55.9 \%)\end{array}$ & $\begin{array}{l}55.4 \mathrm{~b}^{* * * * *} \\
(64.0 \%)\end{array}$ & $\begin{array}{l}40.9 b^{* * * *} \\
(47.1 \%)\end{array}$ & $\begin{array}{l}26.8 \mathrm{~b}^{* * * * *} \\
(37.4 \%)\end{array}$ \\
\hline 5.0 & $\begin{array}{l}72.2 b^{* * * *} \\
(80.8 \%)\end{array}$ & $\begin{array}{l}39.9 \mathrm{~b}^{* * * * *} \\
(46.1 \%)\end{array}$ & $\begin{array}{l}50.0 \mathrm{~b}^{* * * *} \\
(57.6 \%)\end{array}$ & $\begin{array}{l}2.5 \mathrm{c}^{* * * * *} \\
(3.5 \%)\end{array}$ & $\begin{array}{l}27.3 \mathrm{c}^{* * * * *} \\
(30.5 \%)\end{array}$ & $\begin{array}{l}32.8 \mathrm{c}^{* * * * *} \\
(37.9 \%)\end{array}$ & $\begin{array}{l}29.2 \mathrm{c}^{* * * *} \\
(33.6 \%)\end{array}$ & $\begin{array}{l}22.6 \mathrm{~b}^{* * * * *} \\
(31.5 \%)\end{array}$ \\
\hline
\end{tabular}

$\mathrm{x}$ Weight extract per volume water.

y For all days except $P$. rockii Day 3, means within a column followed by the same letter are not significantly different according to Tukey's adjustment for multiple comparisons $(P \leq 0.05)$. For $P$. rockii Day 3, means within a column followed by the same letter are not significantly different according to a KruskalWallis test with Wilcoxon each pair nonparametric multiple comparisons $(P \leq 0.05)$. Significance levels of treatment means versus control means are indicated by *,**,**, and **** (denoting $P \leq 0.05,0.005,0.001$, and 0.0001 , respectively). Values are means of five replicate wells in each of two trials, for a total of $\mathrm{N}=10$. Nematodes were considered viable if they were active following the water rinse, and nonviable if they were not active.

${ }^{\mathrm{z}}$ Numbers in parentheses are percentages of the corresponding water control.

Table 4. Meloidogyne incognita egg hatch and second-stage juvenile activity in extracts from camellia (Camellia oleifera) tea seed cake and tree peony (Paeonia rockii) stems. Eggs were immersed in the extracts, which contained kanamycin $(\mathrm{K})$ to prevent bacterial contamination.

\begin{tabular}{|c|c|c|c|c|c|c|}
\hline \multirow{2}{*}{$\begin{array}{l}\text { Treatment } \\
\text { mg/ml } \mathbf{l}^{\mathbf{x}}\end{array}$} & \multicolumn{6}{|c|}{ Camellia oleifera } \\
\hline & Day $3^{y}$ Hatch & Day $3, \%$ active & Day 5 Hatch & Day $5, \%$ active & Day 7 Hatch & Day $7, \%$ active \\
\hline Water & $25.8 \mathrm{a}$ & $95.7 \mathrm{a}$ & $45.6 \mathrm{a}$ & $95.1 \mathrm{a}$ & $63.3 \mathrm{a}$ & $88.2 b^{* *}$ \\
\hline Water $+\mathrm{K}$ & $16.4 \mathrm{~b}$ & $92.1 \mathrm{a}$ & $35.6 \mathrm{ab}$ & $96.0 \mathrm{a}$ & $52.2 \mathrm{a}$ & $94.1 \mathrm{a}$ \\
\hline 1.0 & $13.7 \mathrm{~b}(83.5 \%)^{\mathrm{z}}$ & $51.9 \mathrm{~b}^{* * * *}(56.4 \%)$ & $23.4 \mathrm{bc}(66.0 \%)$ & $24.8 \mathrm{~b}^{* * * *}(25.8 \%)$ & $30.6 \mathrm{~b}^{* *}(58.6 \%)$ & $19.9 \mathrm{c} * * *(21.1 \%)$ \\
\hline 2.5 & $13.9 \mathrm{~b}(84.8 \%)$ & $17.9 \mathrm{c}^{* * * *}(19.4 \%)$ & $20.1 \mathrm{c} *(56.5 \%)$ & $4.3 \mathrm{c} * * * *(4.5 \%)$ & $21.0 \mathrm{~b}^{* * * *}(40.2 \%)$ & $1.1 \mathrm{~d}^{* * * * *}(1.2 \%)$ \\
\hline 5.0 & $14.4 \mathrm{~b}(87.8 \%)$ & $5.2 \mathrm{~d} * * * *(5.6 \%)$ & $15.8 c^{* * *}(44.4 \%)$ & $0.0 \mathrm{c} * * * *(0 \%)$ & $16.0 \mathrm{~b}^{* * * *}(30.7 \%)$ & $0.0 \mathrm{~d}^{* * * * *}(0 \%)$ \\
\hline
\end{tabular}

$\mathrm{x}$ Weight extract per volume water.

y For all columns except $C$. oleifera Day 7, percent active, means within a column followed by the same letter are not significantly different according to Tukey's adjustment for multiple comparisons $(P \leq 0.05)$. For $C$. oleifera Day 7, percent active, means within a column followed by the same letter are not significantly different according to a Kruskal-Wallis test with Wilcoxon each pair nonparametric multiple comparisons $(P \leq 0.05)$. Significance levels of treatment means versus water $+\mathrm{K}$ control means are indicated by $*, * *, * * *$, and $* * * *$ (denoting $P \leq 0.05,0.005,0.001$, and 0.0001 , respectively). Values are means of five replicate wells in each of two trials, for a total of $\mathrm{N}=10$.

${ }^{\mathrm{z}}$ Numbers in parentheses are percentages of the corresponding water + kanamycin control. 
$\mathrm{J} 2$ activity at $1.0 \mathrm{mg} / \mathrm{ml}$ and $5.0 \mathrm{mg} / \mathrm{ml}$. After the water rinse, all treatments reduced $\mathrm{J} 2$ viability. However, at $5.0 \mathrm{mg} / \mathrm{ml}$, the $P$. rockii extract was more effective than the $P$. suffruticosa extract against J2. In that concentration, reductions in $\mathbf{J} 2$ activity on Day 1 and Day 2 were 41 and $39 \%$, respectively, for $P$. suffruticosa, and loss in viability was $26 \%$ after the water rinse. In $P$. rockii extracts, reductions in activity/viability for Days 1,2 , and 3 were 96, 94, and $80 \%$, respectively.

In assays with the $P$. suffruticosa and $P$. rockii extracts and immersed $M$. incognita eggs, hatch was decreased by $P$. rockii extracts, with a $95 \%$ hatch reduction in $5.0 \mathrm{mg} / \mathrm{ml}$ by Day 7 (Table 6). This was similar to results from the assays conducted with $P$. rockii and camellia (Table 4). In both assays, $P$. rockii extracts suppressed hatch at the highest rates; rates below $2.5 \mathrm{mg} / \mathrm{ml}$ were not effective (Tables 4 and 6). P. suffruticosa extracts did not significantly reduce hatch (Table 6). $P$. rockii $5.0 \mathrm{mg} / \mathrm{ml}$ extracts were highly effective from Day 1; hatch was low on Day 2 and remained low throughout the assay.

In the same assays, $P$. rockii extracts affected activity of $M$. incognita $\mathrm{J} 2$ that hatched from the eggs (Table 7). The greatest decreases on all days occurred in $5.0 \mathrm{mg} / \mathrm{ml}$, and $\mathrm{J} 2$ activity was decreased by $100 \%$ on Day 7 . In general, there was no effect on $\mathrm{J} 2$ activity with $P$. suffruticosa extracts (Table 7). This was similar to results with previously hatched $\mathrm{J} 2$, in which $P$. rockii extract had a greater effect than $P$. suffruticosa extract on $\mathrm{J} 2$ activity and viability (Table 5).

Greenhouse trials with camellia tea seed cake powder and H. glycines. Soybean shoot fresh and dry weights tended to be lower with the two highest camellia powder amendment rates $(0.75 \% \mathrm{wt}$ powder/vol soil and $1.0 \% \mathrm{wt} / \mathrm{vol})$ when compared with controls with and without $H$. glycines (Table 8). There was an exception in Trial 1: shoot fresh weights with these two treatments were similar to weights from control plants without $H$. glycines. Results with the lowest amendment rate, $0.5 \% \mathrm{wt} / \mathrm{vol}$, were also variable. This treatment suppressed shoot fresh weights compared with the $H$. glycines control in Trial 1, did not suppress shoot fresh weight in Trial 2, and resulted in shoot dry weights lower than those in the control without $H$. glycines in both trials. Unlike results with shoots, root fresh weights in Trial 1 were lower in all nematode-inoculated plants than in the plants without nematodes. However, in Trial 2, most root fresh weights were not significantly different among treatments. Only $0.75 \% \mathrm{wt} / \mathrm{vol}$ camellia powder amendment resulted in lower root fresh weights than in the control without $H$. glycines.

Numbers of cysts/root system were decreased by all camellia cake powder treatments (Table 8). Numbers tended to be the lowest in the highest amendment rate, which decreased cysts per root system by $60 \%$ in Trial 1 and $67 \%$ in Trial 2. However, all three rates decreased cyst/root system numbers compared with the control without camellia cake powder. Cysts/g root were also decreased by amendment with camellia powder, with decreases of $52 \%$ in Trial 1 and $66 \%$ in Trial 2 at the highest amendment rate, compared with the control without camellia cake powder. The lowest amendment rate, $0.5 \% \mathrm{wt} /$ vol, decreased cysts/g root by 33 to $34 \%$.

\section{Discussion}

Extracts prepared from $C$. oleifera tea seed cake and $P$. rockii stems inhibited $H$. glycines and $M$. incognita egg hatch and were toxic to $\mathrm{J} 2$. At the highest rates, both types of extracts decreased $H$. glycines hatch by more than half, and resulted in death of nearly all previously hatched $H$. glycines $\mathrm{J} 2$. With $M$. incognita, the highrate $C$. oleifera cake extracts rendered most previously hatched $\mathrm{J} 2$ nonviable and reduced hatch by more than $2 / 3$. P. rockii stem extracts had greater activity against $M$. incognita than $P$. suffruticosa cv. Shimanishiki stem extracts, with the highest $P$. rockii concentration resulting in more than three times as many nonviable $\mathrm{J} 2$ and reducing hatch to less than a tenth of hatch in $P$. suffruticosa extracts. This is the first report on effects of camellia cake extracts and Paeonia spp. stem extracts on $\mathrm{H}$. glycines, and the first comparing activity of two tree peony species against any nematode.

Nematotoxicity of camellia tea seed cake extracts has been found with other phytoparasitic nematodes. At concentrations of $50 \mathrm{mg} / \mathrm{ml}$ and $150 \mathrm{mg} / \mathrm{ml}$, ethanol extracts from tea seed cake killed 40 to $70 \%$ of $M$. javanica $\mathrm{J} 2$, respectively, and inhibited hatch by 66 to $85 \%(\mathrm{Li}$ et al. 2013a). C. oleifera cake extract at $10 \mathrm{mg} / \mathrm{ml}$ resulted in death of up to $90 \%$ of B. xylophilus and an average of $55 \%$ of M. incognita $\mathrm{J} 2$ (Wang et al. 2013). Water extracts from $C$. oleifera cake killed $99 \%$ of $M$. javanica $\mathrm{J} 2$ at doses of 5 to $100 \mathrm{~g} / \mathrm{liter}(5 \mathrm{mg} / \mathrm{ml}$ to $100 \mathrm{mg} / \mathrm{ml})$ (Yang et al. 2015), similar to our results with $H$. glycines and M. incognita $\mathrm{J} 2$ that were immersed directly in ethanolic extracts.

Camellia has many economically important uses, so studies have reported on the phytochemistry of plants in this genus (Cui et al. 2018). Camellia is known for production of triterpenoid saponins, referred to as theasaponins, that are considered environmentally friendly. Hundreds of these saponins have been identified from bark, flower buds, fruit peels, leaves, roots, seeds, and stems of Camellia spp. (Cui et al. 2018). Saponins comprise 15 to $20 \%$ of $C$. oleifera cake (Liu et al. 2016), and 11 theasaponins were identified from the cakes (Cui et al. 2018). Much of the camellia tea seed cake activity is attributed to saponins, which are also derived from other plants and have been shown to be nematicidal to plant-parasitic nematodes, including $M$. incognita, Rotylenchulus reniformis, and Xiphinema index (Ntalli and Caboni 2012). For example, saponins isolated from Pulsatilla koreana, the Korean pasque flower, were active against $M$. incognita in laboratory assays, with $\mathrm{LC}_{50}$ values of 69.7 to $77.6 \mu \mathrm{g} / \mathrm{ml}$ ( $\mathrm{Li}$ et al. 2013b). Saponins in alfalfa (Medicago sativa) acted by disrupting membranes (Ntalli and Caboni 2012), and saponin extracts from alfalfa were active against $M$. incognita, Globodera rostochiensis, and Xiphinema index in vitro (D'Addabbo et al. 2011). Soil amended with dry alfalfa tops or roots reduced $M$. incognita populations on tomato and G. rostochiensis on potato (D'Addabbo et al. 2011). The authors postulated that saponins and other active metabolites, including canavanine and phenolics, may have been involved

Table 4. (Continued from previous page)

\begin{tabular}{llllll}
\hline \multicolumn{1}{c}{ Paeonia rockii } \\
\hline \multicolumn{1}{c}{ Day 3 Hatch } & Day 3, \% active & Day 5 Hatch & Day 5, \% active & Day 7 Hatch & Day 7, \% active \\
\hline $25.8 \mathrm{a}$ & $95.7 \mathrm{a}$ & $45.6 \mathrm{a}$ & $95.1 \mathrm{a}$ & $63.3 \mathrm{a}$ & $88.2 \mathrm{ab}$ \\
$16.4 \mathrm{~b}$ & $92.1 \mathrm{a}$ & $35.6 \mathrm{ab}$ & $96.0 \mathrm{a}$ & $52.2 \mathrm{a}$ & $94.1 \mathrm{a}$ \\
$22.1 \mathrm{ab}(134.8 \%)$ & $88.6 \mathrm{a}(96.3 \%)$ & $37.0 \mathrm{ab}(103.9 \%)$ & $85.2 \mathrm{ab}(88.8 \%)$ & $53.1 \mathrm{a}(101.7 \%)$ & $78.6 \mathrm{~b}(83.5 \%)$ \\
$15.5 \mathrm{~b}(94.5 \%)$ & $87.8 \mathrm{a}(95.3 \%)$ & $26.7 \mathrm{~b}(75.0 \%)$ & $77.1 \mathrm{~b} * * *(80.3 \%)$ & $32.4 \mathrm{~b} *(62.1 \%)$ & $81.2 \mathrm{ab}(86.3 \%)$ \\
$2.1 \mathrm{c} * * * *(12.8 \%)$ & $7.5 \mathrm{~b} * * *(8.1 \%)$ & $3.4 \mathrm{c} * * *(9.6 \%)$ & $20.4 \mathrm{c}^{* * * *}(21.3 \%)$ & $3.0 \mathrm{c}^{* * * *}(5.7 \%)$ & $18.7 \mathrm{c} * * * *(19.9 \%)$ \\
\hline
\end{tabular}


in the suppression, along with ammonia release as the amendments decomposed, and increases in numbers of microbes active against plant-parasitic nematodes. Saponins were also considered to have contributed to $M$. incognita suppression when soil was amended with 20 or 40 ton/ha of alfalfa meal in a pellet form, which also increased tomato yield (Leonetti et al. 2011).

Studies with $C$. oleifera cake as a soil amendment, and saponins from the cake, have demonstrated nematocidal activity. In our greenhouse trials, powdered $C$. oleifera cake suppressed $H$. glycines cyst numbers by up to $66 \%$. The amendment rates, when applied to individual plants in a field at 5.0,7.5, and $10.0 \mathrm{~g} /$ liter, would correspond to ca. $150 \mathrm{~kg} / \mathrm{ha}, 225 \mathrm{~kg} / \mathrm{ha}$, and $300 \mathrm{~kg} / \mathrm{ha}$. Camellia sasauqua cake powder amended into soil at $9-11 \mathrm{~g} /$ liter reduced egg numbers by 70 to $80 \%$ on water spinach and Malabar spinach (Li et al. 2013a). A saponin extract from $C$. oleifera cake, applied at 0.75 and $1.5 \mathrm{~g} / \mathrm{kg}$ to soil in a pot experiment, reduced $M$. incognita galling on tomato (Wang et al. 2013). The same authors found that $C$. oleifera cake applied at $2.5 \mathrm{t} /$ ha reduced reproduction of $M$. incognita on Chinese cucumber. Saponin from $C$. oleifera cake was nematicidal to $M$. javanica, with $100 \%$ mortality in $70 \mathrm{~g} /$ liter, while volatile compounds from cake extract killed nearly $100 \%$ of $\mathrm{J} 2$ at $50 \mathrm{~g} /$ liter (Yang et al. 2015). In pot experiments, soil application rates of 1,2 , and $5 \mathrm{~g}$ cake/kg soil generally resulted in decreased nematode densities on banana plants (Yang et al. 2015). No phytotoxicity was observed, likely because the banana seedlings were transplanted 7 days after soil amendment with $C$. oleifera cake. Eight volatile compounds identified from the seed cake were nematicidal to $M$. javanica, including 1-butanol, 2-methyl-butanoic acid, 1-octen-3-ol, butylester butanoic acid, 2-methylbutanebutyl, 3,3-dimethyloctane, 4-methylphenol, and 2-bromo dodecane. The authors concluded that these also contributed to nematode suppression, and that nutrients in the cake played a role in improving plant vigor (Yang et al. 2015). Additional studies with $C$. oleifera cake also indicated that banana seedling transplant should take place 7 days after soil amendment to avoid phytotoxicity; transplanting after that time improved plant vigor with a cake amendment of $5 \mathrm{~g} / \mathrm{kg}$ soil. The seed cake increased numbers of free-living nematodes and soil microbes, and decreased numbers of plant-parasitic nematodes (Yang et al. 2018). Some phytotoxicity to soybean was observed in our greenhouse experiments. However, even the lowest tested seed cake application rate resulted in suppression of $H$. glycines. Future studies would indicate whether low rates in the field, applied a week or more before seeding, would result in nematotoxicity without phytotoxicity.

Our study demonstrated that tree peony stem extracts were nematicidal to $H$. glycines and $M$. incognita. In the only prior investigation with tree peony stem components and phytoparasitic nematodes, $P$. rockii (reported as $P$. suffruticosa) stem extracts were tested against B. xylophilus, $M$. arenaria, and Hirschmanniella oryzae

Table 5. Meloidogyne incognita second-stage juvenile (J2) activity and viability in extracts from stems of two tree peony species: Paeonia suffruticosa cv. Shimanishiki (nursery-grown in the United States) and Paeonia rockii (naturally growing in China). Previously hatched J2 were immersed in the extracts.

\begin{tabular}{|c|c|c|c|c|c|c|}
\hline \multirow{2}{*}{$\begin{array}{l}\text { Treatment } \\
\text { mg/ml }^{\mathbf{x}}\end{array}$} & \multicolumn{3}{|c|}{ Paeonia suffruticosa } & \multicolumn{3}{|c|}{ Paeonia rockii } \\
\hline & Day $1^{y}, \%$ active & Day $2, \%$ active & Day 3, rinsed \% viable & Day $1, \%$ active & Day $2, \%$ active & Day 3, rinsed \% viable \\
\hline Water ${ }^{\mathrm{y}}$ & $96.8 \mathrm{aA}$ & $94.4 \mathrm{aA}$ & $81.5 \mathrm{aB}$ & $96.8 \mathrm{aA}$ & $94.4 \mathrm{aA}$ & $81.5 \mathrm{aB}$ \\
\hline 0.25 & $93.1 \mathrm{abA}(96.2 \%)^{\mathrm{Z}}$ & $74.9 \mathrm{bB} * * * *(79.3 \%)$ & 55.6 bC**** $(68.2 \%)$ & $84.2 \mathrm{bcAB} * * * *(87.0 \%)$ & 76.0 bB**** $(80.5 \%)$ & 57.0 bC**** $(69.9 \%)$ \\
\hline 0.5 & $78.1 \mathrm{cA}^{* * * *}(80.7 \%)$ & $65.3 \mathrm{bcAB} * * * *(69.2 \%)$ & $45.4 \mathrm{bC} * * * *(55.7 \%)$ & $80.7 \mathrm{bcA} * * *(83.4 \%)$ & $64.7 \mathrm{bcAB} * * * *(68.5 \%)$ & $51.6 \mathrm{bBC}^{* * * *}(63.3 \%)$ \\
\hline 1.0 & $71.0 \mathrm{cdA} * * * *(73.3 \%)$ & $61.1 \mathrm{cAB} * * * *(64.7 \%)$ & $49.1 \mathrm{bB} * * * *(60.2 \%)$ & $63.6 \mathrm{de} \mathrm{AB}^{* * * *}(65.7 \%)$ & $62.4 \mathrm{cAB} * * * *(66.1 \%)$ & $59.7 \mathrm{bAB} * * * *(73.3 \%)$ \\
\hline 5.0 & $56.7 \mathrm{eA} * * * *(58.6 \%)$ & $57.3 \mathrm{cA} * * * *(60.7 \%)$ & $60.5 \mathrm{bA} * * *(74.2 \%)$ & $3.9 \mathrm{fC}^{* * * *}(4.0 \%)$ & $5.7 \mathrm{dBC}^{* * * *}(6.0 \%)$ & $16.0 \mathrm{cB} * * * *(19.6 \%)$ \\
\hline
\end{tabular}

$\mathrm{x}$ Weight extract per volume water.

y For all days except Day 1, means within the two columns for that day (one column for each tree peony species) followed by the same lowercase letter are not significantly different according to Tukey's adjustment for multiple comparisons $(P \leq 0.05)$. For Day 1, means within the two columns for that day (one column for each tree peony species) followed by the same lowercase letter are not significantly different according to a Kruskal-Wallis test with Wilcoxon each pair nonparametric multiple comparisons $(P \leq 0.05)$. For all treatments, means within a row followed by the same uppercase letter are not significantly different according to Tukey's adjustment for multiple comparisons $(P \leq 0.05)$. Within columns, significance levels of treatment means versus water control means are indicated by $*, * *, * * *$, and $* * * *$ (denoting $P \leq 0.05,0.005,0.001$, and 0.0001 , respectively). Values are means of five replicate wells in each of two trials, for a total of $\mathrm{N}=10$. Nematodes were considered viable if they were active following the water rinse, and nonviable if they were not active.

${ }^{\mathrm{z}}$ Numbers in parentheses are percentages of the corresponding water control.

Table 6. Meloidogyne incognita egg hatch in extracts from stems of two tree peony species: Paeonia suffruticosa cv. Shimanishiki (nursery-grown in the United States) and Paeonia rockii (naturally growing in China). Eggs were immersed in the extracts, which contained kanamycin (K) to prevent bacterial contamination.

\begin{tabular}{|c|c|c|c|c|c|c|}
\hline \multirow{2}{*}{$\begin{array}{l}\text { Treatment } \\
\mathbf{m g} / \mathbf{m l}^{\mathbf{x}}\end{array}$} & \multicolumn{3}{|c|}{ Paeonia suffruticosa } & \multicolumn{3}{|c|}{ Paeonia rockii } \\
\hline & Day $2^{y}$ Hatch & Day 5 Hatch & Day 7 Hatch & Day 2 Hatch & Day 5 Hatch & Day 7 Hatch \\
\hline Water ${ }^{\mathrm{y}}$ & $5.1 \mathrm{abC}$ & $20.4 \mathrm{abB}$ & $34.9 \mathrm{aA}$ & $5.1 \mathrm{abC}$ & $20.4 \mathrm{abB}$ & $34.9 \mathrm{aA}$ \\
\hline Water $+\mathrm{K}$ & $3.2 \mathrm{bcC}$ & $17.0 \mathrm{abB}$ & $24.6 \mathrm{abcA}$ & $3.2 \mathrm{bcC}$ & $17.0 \mathrm{abB}$ & $24.6 \mathrm{abcA}$ \\
\hline \multirow[t]{2}{*}{0.25} & $5.9 \mathrm{abC}$ & $18.5 \mathrm{abB}$ & 28.9 abcA & $4.1 \mathrm{bC}$ & $19.1 \mathrm{abB}$ & $27.8 \mathrm{abcA}$ \\
\hline & $(184.4 \%)^{\mathrm{z}}$ & $(108.8 \%)$ & $(117.5 \%)$ & $(128.1 \%)$ & $(112.4 \%)$ & $(113.0 \%)$ \\
\hline \multirow[t]{2}{*}{0.50} & $6.0 \mathrm{abC}$ & $20.0 \mathrm{abB}$ & $30.9 \mathrm{abA}$ & $5.2 \mathrm{abC}$ & $20.0 \mathrm{abB}$ & $30.6 \mathrm{abA}$ \\
\hline & $(187.5 \%)$ & $(117.6 \%)$ & $(125.6 \%)$ & $(162.5 \%)$ & $(117.6 \%)$ & $(124.4 \%)$ \\
\hline \multirow[t]{2}{*}{1.0} & $7.1 \mathrm{aDE} * * *$ & $23.5 \mathrm{aB}$ & $33.1 \mathrm{aA}$ & $3.8 \mathrm{bE}$ & $13.6 \mathrm{bCD}$ & $20.9 \mathrm{bcBC}$ \\
\hline & $(221.9 \%)$ & $(138.2 \%)$ & $(134.6 \%)$ & $(118.8 \%)$ & $(80.0 \%)$ & $(85.0 \%)$ \\
\hline \multirow[t]{2}{*}{5.0} & $4.8 \mathrm{abC}$ & $13.9 \mathrm{bB}$ & $19.7 \mathrm{cA}$ & $0.8 \mathrm{cD}$ & $1.1 \mathrm{cD}^{* * * *}$ & $1.3 \mathrm{dD} * * * *$ \\
\hline & (150.0\%) & $(81.8 \%)$ & $(80.1 \%)$ & $(25.0 \%)$ & $(6.5 \%)$ & $(5.3 \%)$ \\
\hline
\end{tabular}

${ }^{\mathrm{x}}$ Weight extract per volume water.

y For all days, means within the two columns for that day (one column for each tree peony species) followed by the same lowercase letter are not significantly different according to Tukey's adjustment for multiple comparisons $(P \leq 0.05)$. For all treatments, means within a row followed by the same uppercase letter are not significantly different according to Tukey's adjustment for multiple comparisons $(P \leq 0.05)$. Within columns, significance levels of treatment means versus water $+\mathrm{K}$ control means are indicated by *,**,***, and **** (denoting $P \leq 0.05,0.005,0.001$, and 0.0001 , respectively). Values are means of five replicate wells in each of two trials, for a total of $\mathrm{N}=10$. Nematodes were considered viable if they were active following the water rinse, and nonviable if they were not active.

${ }^{\mathrm{z}}$ Numbers in parentheses are percentages of the corresponding water + kanamycin control. 
(Wen et al. 2001). With a dose of $1 \mathrm{mg} / \mathrm{ml}$, proliferation of B. xylophilus mixed stages was reduced by $84 \%$, and activity of $M$. arenaria and Hirschmanniella oryzae J2 by 100 and $86 \%$, respectively. In other research with tree peonies, essential oil from $P$. suffruticosa (reported by the syn. P. moutan) roots killed $100 \%$ of B. xylophilus males, females, and adults at $2 \mathrm{mg} / \mathrm{ml}$ (Choi et al. 2007). Tannins (1, 2, 3 , 4, 6-penta ${ }^{12)}-O$-galloyl- $\beta$-D-glucose and a condensed tannin (proanthocyanidin) polymer) isolated from fresh $P$. suffruticosa leaves and tested against Caenorhabditis elegans had $\mathrm{LC}_{50}$ values of 15.4 and $5.3 \mu \mathrm{g} / \mathrm{ml}$, respectively (Mohamed et al. 2000). P. suffruticosa root bark ground into a powder and amended into soil at $0.2 \%$ (weight dried plant material/volume soil) reduced $M$. incognita root galling on tomato by $95.3 \%$. The authors of the latter study suggested that the rates might be high for field use but applicable to more commercially valuable crops (Kim et al. 2003). These studies indicate the possibility that tree peony constituents might act as natural nematicides.

While there is reason for further work on these natural products, it is notable that extracts from the two tree peony species had different effects on $M$. incognita. $P$. rockii stem extract exhibited greater nematotoxicity, killing up to $80 \%$ of previously hatched $\mathrm{J} 2$, as opposed to $26 \%$ in the $P$. suffruticosa stem extract. Hatch in $P$. rockii extract at $5.0 \mathrm{mg} / \mathrm{ml}$ was $7 \%$ of the hatch in $P$. suffruticosa extract. J2 that hatched from immersed eggs were not affected by $P$. suffruticosa stem extract, while none were active in $P$. rockii stem extract. These results were likely due to such factors as differences in plant genotypes, growth conditions of the plants, or even some slight variations in extract preparation. While chemical constituents of flowers, leaves, and roots of tree peony have been studied (Bao et al. 2018; Li et al. 2018), chemistry of the stems has not been investigated. However, a study on roots of 372 tree peony cultivars identified 42 metabolites, and demonstrated that there were seven groups based on variations from low to high amounts of metabolites ( $\mathrm{Li}$ et al. 2018). The tree peony taxa that we used for our assays were not tested by Li et al. (2018), but their results clearly showed that metabolites vary with tree peony cultivar.

The current research indicates that $C$. oleifera tea seed cake has potential for use as a soil amendment for managing nematodes on crop plants. Tests can be conducted to determine if phytotoxicity occurs on crops in the field, and if so, various times between soil amendment and planting or transplanting can be tested for eliminating any phytotoxic effects. Field studies will indicate whether suppression of nematode populations occurs at an amendment rate that will be useful for a field crop like soybean, or better applied to a specialty crop. Extracts from Paeonia spp. stems also demonstrate activity against these nematodes, with different nematotoxicity between the wild type plant and the cultivar. While stems are not being investigated for use as soil amendments, further work on identification of active compounds from $P$. rockii may yield metabolites that can be applied as biobased nematicides.

Table 7. Meloidogyne incognita second-stage juvenile activity after hatch from eggs immersed in extracts from stems of two tree peony species: Paeonia suffruticosa cv. Shimanishiki (nursery-grown in the United States) and Paeonia rockii (naturally growing in China)

\begin{tabular}{|c|c|c|c|c|c|c|}
\hline \multirow{2}{*}{$\begin{array}{l}\text { Treatment } \\
\text { mg/ml }\end{array}$} & \multicolumn{3}{|c|}{ Paeonia suffruticosa } & \multicolumn{3}{|c|}{ Paeonia rockii } \\
\hline & Day $2^{y}, \%$ active & Day 5, \% active & Day $7, \%$ active & Day $2, \%$ active & Day 5, \% active & Day $7, \%$ active \\
\hline Water ${ }^{y}$ & $73.1 \mathrm{abA}$ & $94.5 \mathrm{aA}$ & $94.8 \mathrm{aA}$ & $73.1 \mathrm{abA}$ & $94.5 \mathrm{aA}$ & $94.8 \mathrm{aA}$ \\
\hline Water + K & 50.8 abB & $92.1 \mathrm{aA}$ & $94.0 \mathrm{abA}$ & $50.8 \mathrm{abB}$ & $92.1 \mathrm{aA}$ & $94.0 \mathrm{abA}$ \\
\hline 0.25 & $\begin{array}{r}74.8 \mathrm{bA} \\
(147.2 \%)^{\mathrm{z}}\end{array}$ & $\begin{array}{l}89.6 \mathrm{aA} \\
(97.4 \%)\end{array}$ & $\begin{array}{l}84.0 \mathrm{dA}^{*} \\
(89.4 \%)\end{array}$ & $\begin{array}{l}74.7 \mathrm{abA} \\
(147.0 \%)\end{array}$ & $\begin{array}{l}91.3 \mathrm{aA} \\
(99.2 \%)\end{array}$ & $\begin{array}{l}92.2 \mathrm{abcA} \\
(98.1 \%)\end{array}$ \\
\hline 0.50 & $\begin{array}{l}79.5 \mathrm{abAB} \\
(156.5 \%)\end{array}$ & $\begin{array}{l}90.4 \mathrm{aA} \\
(98.3 \%)\end{array}$ & $\begin{array}{l}84.9 \mathrm{dAB}^{*} \\
(90.3 \%)\end{array}$ & $\begin{array}{l}70.3 \mathrm{abB} \\
(138.4 \%)\end{array}$ & $\begin{array}{l}89.5 \mathrm{aA} \\
(97.3 \%)\end{array}$ & $\begin{array}{l}85.9 \text { cdAB* } \\
(91.4 \%)\end{array}$ \\
\hline 1.0 & $\begin{array}{c}87.8 \mathrm{aA} \\
(172.8 \%)\end{array}$ & $\begin{array}{l}90.4 \mathrm{aA} \\
(98.3 \%)\end{array}$ & $\begin{array}{l}84.5 \text { bcdA } \\
(89.9 \%)\end{array}$ & $\begin{array}{l}74.8 \mathrm{abAB} \\
(147.2 \%)\end{array}$ & $\begin{array}{l}87.3 \mathrm{aA} \\
(94.9 \%)\end{array}$ & $\begin{array}{l}68.9 \mathrm{fB}^{* * *} \\
(73.3 \%)\end{array}$ \\
\hline 5.0 & $\begin{array}{l}80.5 \mathrm{abA} \\
(158.5 \%)\end{array}$ & $\begin{array}{l}77.9 \mathrm{aA} \\
(84.7 \%)\end{array}$ & $\begin{array}{l}79.9 \text { abcdeA*** } \\
(85.0 \%)\end{array}$ & $\begin{array}{l}10.0 \mathrm{cB}^{*} \\
(19.7 \%)\end{array}$ & $\begin{array}{l}15.0 \mathrm{bB} * * * * \\
(16.3 \%)\end{array}$ & $\begin{array}{l}0.0 \mathrm{gB} * * * * \\
(0 \%)\end{array}$ \\
\hline
\end{tabular}

${ }^{\mathrm{x}}$ Weight extract per volume water.

${ }^{y}$ For Day 5, means within the two columns for that day (one column for each tree peony species) followed by the same lowercase letter are not significantly different according to Tukey's adjustment for multiple comparisons $(P \leq 0.05)$. For Days 2 and 7 , means within the two columns for that day (one column for each tree peony species) followed by the same lowercase letter are not significantly different according to a Kruskal-Wallis test with Wilcoxon each pair nonparametric multiple comparisons $(P \leq 0.05)$. For treatments $0.25 \mathrm{mg} / \mathrm{ml}$ and $0.5 \mathrm{mg} / \mathrm{ml}$, means within a row followed by the same uppercase letter are not significantly different according to Tukey's adjustment for multiple comparisons $(P \leq 0.05)$. For treatments water, water $+\mathrm{K}, 1.0 \mathrm{mg} / \mathrm{ml}$ and 5.0 $\mathrm{mg} / \mathrm{ml}$, means within a row followed by the same uppercase letter are not significantly different according to a Kruskal-Wallis test with Wilcoxon each pair nonparametric multiple comparisons $(P \leq 0.05)$. Within columns, significance levels of treatment means versus water $+\mathrm{K}$ control means are indicated by $*, * *, * * *$, and ***** (denoting $P \leq 0.05,0.005,0.001$, and 0.0001 , respectively). Values are means of five replicate wells in each of two trials, for a total of $\mathrm{N}=10 . \mathrm{Nematodes}$ were considered viable if they were active following the water rinse, and nonviable if they were not active.

${ }^{\mathrm{z}}$ Numbers in parentheses are percentages of the corresponding water $+\mathrm{K}$ control.

Table 8. Effect of soil amendment with powdered camellia (Camellia oleifera) tea seed cake on soybean (Glycine max cv. Essex) plant vigor, with and without Heterodera glycines, and on cyst numbers on soybean roots. Amendments were applied on the day of seedling transplant. Soybean plants were harvested 33 days after transplant.

\begin{tabular}{|c|c|c|c|c|c|c|c|c|c|c|}
\hline \multirow[b]{2}{*}{ Treatment $^{\mathbf{y}}$} & \multicolumn{2}{|c|}{$\begin{array}{l}\text { Shoot fresh } \\
\text { weight }(g)^{z}\end{array}$} & \multicolumn{2}{|c|}{$\begin{array}{l}\text { Shoot dry } \\
\text { weight (g) }\end{array}$} & \multicolumn{2}{|c|}{$\begin{array}{l}\text { Root fresh } \\
\text { weight (g) }\end{array}$} & \multicolumn{2}{|c|}{$\begin{array}{c}\text { Cysts/root } \\
\text { system }\end{array}$} & \multicolumn{2}{|c|}{$\begin{array}{c}\text { Cysts/g root fresh } \\
\text { weight }\end{array}$} \\
\hline & Trial 1 & Trial 2 & Trial 1 & Trial 2 & Trial 1 & Trial 2 & Trial 1 & Trial 2 & Trial 1 & Trial 2 \\
\hline $0 \mathrm{~g}$, No $H$. glycines & $10.8 \mathrm{ab}$ & $11.3 \mathrm{a}$ & $2.8 \mathrm{a}$ & $3.2 \mathrm{a}$ & $11.1 \mathrm{a}$ & $5.4 \mathrm{a}$ & NA & NA & NA & NA \\
\hline $0 \mathrm{~g}+H$. glycines & $11.8 \mathrm{a}$ & $11.3 \mathrm{a}$ & $2.8 \mathrm{ab}$ & $3.0 \mathrm{ab}$ & $8.4 \mathrm{~b} * * *$ & $4.8 \mathrm{ab}$ & $107.3 \mathrm{a}$ & $977.0 \mathrm{a}$ & $12.9 \mathrm{a}$ & $209.5 \mathrm{a}$ \\
\hline $1.5 \mathrm{~g}(0.5 \% \mathrm{w} / \mathrm{v})+H$. glycines & $9.9 \mathrm{~b}$ & $9.6 \mathrm{ab}$ & $2.4 \mathrm{bc} *$ & $2.5 \mathrm{bc} * *$ & $7.9 \mathrm{bc} * * * *$ & $4.6 \mathrm{ab}$ & $62.6 \mathrm{~b}^{* * * *}$ & $613.0 \mathrm{~b}^{*}$ & $8.5 b^{*}$ & $141.3 \mathrm{ab}$ \\
\hline $2.25 \mathrm{~g}(0.75 \% \mathrm{w} / \mathrm{v})+H$. glycines & $9.5 \mathrm{~b}$ & $8.5 \mathrm{~b}^{* *}$ & $2.2 \mathrm{c} * * *$ & $2.3 \mathrm{c} * * *$ & $7.0 \mathrm{c} * * * *$ & $4.1 \mathrm{~b}^{*}$ & $50.9 \mathrm{~b}^{* * * * *}$ & $374.0 \mathrm{bc} * * * * *$ & $7.5 \mathrm{~b} * *$ & $93.1 \mathrm{~b}^{* * *}$ \\
\hline $3.0 \mathrm{~g}(1.0 \% \mathrm{w} / \mathrm{v})+H$. glycines & $10.0 \mathrm{~b}$ & $9.1 \mathrm{~b}^{*}$ & $2.2 \mathrm{c} * * *$ & $2.2 \mathrm{c} * * * *$ & $7.2 \mathrm{bc} * * * *$ & $4.4 \mathrm{ab}$ & $43.5 \mathrm{~b} * * * *$ & $320.0 \mathrm{c} * * * *$ & $6.2 \mathrm{~b} * * *$ & $71.7 \mathrm{~b}^{* * * * *}$ \\
\hline
\end{tabular}

y Grams powder per $300 \mathrm{~cm}^{3}$ soil (followed by \% weight/volume).

${ }^{z}$ For each plant part and trial, means within a column followed by the same letter are not significantly different according to Tukey's adjustment for multiple comparisons $(P \leq 0.05)$. Means are not comparable among columns. Within columns, significance levels of treatment means versus No $H$. glycines control means are indicated by $*, * *, * * *$, and $* * * *$ (denoting $P \leq 0.05,0.005,0.001$, and 0.0001 , respectively). Values are means of 10 replicate pots per trial for each treatment. 


\section{Acknowledgments}

Thanks are extended to Dr. Walter Mulbry for assistance with grinding plant materials.

\section{Literature Cited}

Bao, Y., Qu, Y., Li, J., Li, Y., Ren, X., Maffucci, K. G., Li, R., Wang, Z., and Zeng, R. 2018. In vitro and in vivo antioxidant activities of the flowers and leaves from Paeonia rockii and identification of their antioxidant constituents by UHPLC-ESI-HRMSn via pre-column DPPH reaction. Molecules 23:392. Online publication. doi:10.3390/molecules23020392

Choi, I.-H., Park, J.-Y., Shin, S.-C., Kim, J., and Park, I.-K. 2007. Nematicidal activity of medicinal plant essential oils against the pinewood nematode (Bursaphelenchus xylophilus). Appl. Entomol. Zool. (Jpn.) 42:397-401.

Cui, C., Zong, J., Sun, Y., Zhang, L., Ho, C.-T., Wan, X., and Hou, R. 2018. Triterpenoid saponins from the genus Camellia: Structures, biological activities, and molecular simulation for structure-activity relationship. Food Funct. 9:3069-3091.

D’Addabbo, T., Carbonara, T., Leonetti, P., Radicci, V., Tava, A., and Avato, P. 2011. Control of plant-parasitic nematodes with active saponins and biomass from Medicago sativa. Phytochem. Rev. 10:503-519.

Gong, W., Huang, Y., Ji, A., Peng, W., Liu, C., Zeng, Y., Yang, R., Yan, L., Wang, X., and Sheng, J. 2018. Optimisation of saponin extraction conditions with Camellia sinensis var. assamica seed and its application for a natural detergent. J. Sci. Food Agric. 98:2312-2319.

Hu, J.-L., Nie, S.-P., Huang, D.-F., Li, C., Xie, M.-Y., and Wan, Y. 2012. Antimicrobial activity of saponin-rich fraction from Camellia oleifera cake and its effect on cell viability of mouse macrophage RAW 264.7. J. Sci. Food Agric. 92:2443-2449.

Kijprayoon, S., Tolieng, V., Petsom, A., and Chaicharoenpong, C. 2014. Molluscicidal activity of Camellia oleifera seed meal. Sci. Asia 40:393-399.

Kim, Y. H., Khan, H. U., Kim, J. H., Jeon, Y. H., Lee, E. J., and Chang, S. P. 2003. Efficacy of soil amendment with medicinal plant materials for the control of rootknot nematode (Meloidogyne incognita) in tomato. Plant Pathol. J. 19:138-142.

Leonetti, P., D'Addabbo, T. D., Tava, A., and Avato, P. 2011. Control of root-knot nematodes with biomasses from alfalfa (Medicago sativa $\mathrm{L}$.) and their bioactive saponins. Acta Hortic.: 225-228.

Li, L.-L., Liao, J.-L., and Wen, Y.-H. 2013a. Nematicidal activity of ethanol extracts from tea cakes against Meloidogyne javanica. J. Northwest A\&F Univ. (Nat. Sci. Ed.) 41:73-77.
Li, S.-S., Wu, Q., Yin, D.-D., Feng, C.-Y., Liu, Z.-A., and Wang, L.-S. 2018 Phytochemical variation among the traditional Chinese medicine Mu Dan Pi from Paeonia suffruticosa (tree peony). Phytochemistry 146:16-24.

Li, W., Sun, Y. N., Yan, X. T., Yang, S. Y., Lee, S. J., Byun, H. J., Moon, C. S. Han, B. S., and Kim, Y. H. 2013b. Isolation of nematicidal triterpenoid saponins from Pulsatilla koreana root and their activities against Meloidogyne incognita. Molecules 18:5306-5316. Online publication. doi:10.3390/molecules 18055306

Liu, Y., Li, Z., Xu, H., and Han, Y. 2016. Extraction of saponin from Camellia oleifera Abel cake by a combination method of alkali solution and acid isolation. J. Chem. 2016:Article ID 6903524. Online publication. doi: 10.1155/2016/6903524

Meyer, S. L. F., Chauhan, K. R., and MacDonald, M. H. 2016. Evaluation of roselle (Hibiscus sabdariffa) leaf and pomegranate (Punica granatum) fruit rind for activity against Meloidogyne incognita. Nematropica 46:85-96.

Meyer, S. L. F., Zasada, I. A., Roberts, D. P., Vinyard, B. T., Lakshman, D. K. Lee, J.-K., Chitwood, D. J., and Carta, L. K. 2006. Plantago lanceolata and Plantago rugelii extracts are toxic to Meloidogyne incognita but not to certain microbes. J. Nematol. 38:333-338.

Mohamed, A. S. A., Mori, T., Islam, S. Q., Sato, M., and Yamasaki, T. 2000. Lethal activity of gallo- and condensed tannins against the free-living soilinhabiting nematode, Caenorhabditis elegans. J. Pestic. Sci. 25:410-415.

Ntalli, N. G., and Caboni, P. 2012. Botanical nematicides: A review. J. Agric. Food Chem. 60:9929-9940.

Park, S. D., Khan, Z., and Kim, Y. H. 2007. Evaluation of medicinal herbs for resistance to root-knot nematode, Meloidogyne incognita, in Korea. Nematropica 37:73-77.

Wang, L.-P., Wan, X.-C., Hou, R.-Y., Xu, J.-F., and Wu, H.-P. 2013. Control of Camellia plant extracts and its preparation against plant-parasitic nematodes. J. Anhui Agric. Univ. 40:642-648.

Wen, Y., Feng, Z., Xu, H., and Chen, L. 2001. Screening for nematicidal activity of some Chinese plant extracts against plant-parasitic nematodes, Bursaphelenchus xylophilus, Meloidogyne arenaria and Hirschmanniella oryzae. J. Huazhong Agric. Univ. 20:235-238.

Yang, X., Wang, X., Wang, K., Su, L., Li, H., Li, R., and Shen, Q. 2015. The nematicidal effect of Camellia seed cake on root-knot nematode Meloidogyne javanica of banana. PLoS ONE 10:e0119700. Online publication. doi:10.1371/journal.pone.0119700

Yang, X., Xue, C., Su, L., Cao, Y., Li, H., Wang, K., Li, R., and Shen, Q. 2018. Exploring patterns of Camellia seed cake application in relation to plant growth, soil nematodes and microbial biomass. Soil Sci. Plant Nutr. 64: 253-264. 